\title{
Clinal variation in investment into reproduction versus maintenance suggests a 'pace-of-life' syndrome in a widespread butterfly
}

\author{
Franziska Günter $^{1}$ D $\cdot$ Michaël Beaulieu ${ }^{1} \cdot$ Kristin Franke $^{1} \cdot$ Nia Toshkova $^{2} \cdot$ Klaus Fischer $^{1,3}$
}

Received: 10 April 2020 / Accepted: 21 July 2020 / Published online: 27 July 2020

(c) The Author(s) 2020

\begin{abstract}
Extreme weather events such as heat waves are predicted to increase in the course of anthropogenic climate change. Widespread species are exposed to a variety of environmental conditions throughout their distribution range, often resulting in local adaptation. Consequently, populations from different regions may vary in their capacity to deal with challenging conditions such as thermal stress. In this study, we investigated clinal variation in body size, fecundity, and oxidative markers along a pan-European latitudinal gradient in the green-veined white butterfly Pieris napi, and additionally gene expression in German individuals. We exposed butterflies from replicated Italian, German, and Swedish populations to cold, control, or hot temperatures for $24 \mathrm{~h}$. Under hot conditions, molecular chaperones were up-regulated, while oxidative damage remained unaffected and levels of the antioxidant glutathione (GSH) were reduced under cold and hot conditions. Thus, the short-term exposure to heat stress did not substantially affect oxidative balance. Moreover, we found decreased body size and fecundity in cooler compared with warmer regions. Interestingly, oxidative damage was lowest in Swedish animals exhibiting (1) high levels of GSH, (2) low early fecundity, and (3) low larval growth rates. These results suggest that Swedish butterflies have a slower life style and invest more strongly into maintenance, while those from warmer regions show the opposite pattern, which may reflect a 'pace-of-life' syndrome.
\end{abstract}

Keywords Heat stress $\cdot$ Local adaptation $\cdot$ Molecular chaperones $\cdot$ Oxidative stress $\cdot$ Pieris napi

\section{Introduction}

The significance of climate change, potentially affecting all organisms, is becoming more and more evident (Parmesan and Yohe 2003; Deutsch et al. 2008). Global surface temperatures rise, while precipitation patterns become more

Communicated by Konrad Fiedler.

Electronic supplementary material The online version of this article (https://doi.org/10.1007/s00442-020-04719-4) contains supplementary material, which is available to authorized users.

Franziska Günter

Franziska.guenter@uni-greifswald.de

1 Zoological Institute and Museum, Greifswald University, Soldmannstraße 14, 17489 Greifswald, Germany

2 National Museum of Natural History at the Bulgarian Academy of Science, 1 Tsar Osvoboditel Blvd, 1000 Sofia, Bulgaria

3 Present Address: Institute for Integrated Natural Sciences, University Koblenz-Landau, 56070 Koblenz, Germany variable, which has already changed the distribution of many species (Diffenbaugh et al. 2005; Hansen et al. 2012). In particular, extreme weather events such as heat waves are predicted to increase, which may strongly affect biodiversity (Easterling et al. 2000; Meehl and Tebaldi 2004). To counteract the negative effects of changing environmental conditions, organisms may respond, in addition to shifting their range, through phenotypic plasticity and/or genetic adaption, thereby enhancing their performance under the novel environmental conditions which they encounter (Pigliucci 2001).

In widespread species, spatial variation in fitness-related traits often reflects differences in selective pressures, resulting in local adaptation (Ellers and Boggs 2002; Kawecki and Ebert 2004; Stillwell and Fox 2009). Clinal variation may indicate such local adaptation, as geographical clines are strongly related to environmental gradients, which may pose differential challenges to survival and reproduction. A well-known example of clinal variation is an increase in body size with increasing latitude (Bergmann size clines), the adaptive value of which though is not entirely clear with regard to ectotherms (Arnett and Gotelli 1999; Robinson and 
Partridge 2001; Chown and Klok 2003). Indeed, short season length and low ambient temperature at higher latitudes may select for fast growth, which may result in converse Bergmann clines (Van Doorslaer and Stoks 2005). In the face of anthropogenic climate change, investigating widespread species showing local adaptation is important, as such species may respond differently across their distribution range to ongoing environmental change depending on their genetically based plastic capacities (Addo-Bediako et al. 2000; Hoffmann and Rieseberg 2008; Kapun et al. 2016).

Plastic responses to environmental change entail a large number of relatively fast physiological mechanisms. In response to thermally challenging conditions, two mechanisms seem to be of particular importance, antioxidant defence mechanisms and the heat shock response (Sørensen et al. 2003; Zhang et al. 2015; Franke et al. 2019). High temperatures generally increase the production of reactive oxygen species (ROS), a by-product of the aerobic metabolism, which act on organic substrates and may induce oxidative damage. This can, for instance, be measured with markers of lipid peroxidation such as malondialdehyde (MDA; Beaulieu et al. 2015; Zhang et al. 2015). To prevent oxidative damage induced by high temperatures, organisms may upregulate various antioxidant compounds, including the non-enzymatic antioxidant glutathione (GSH; Lalouette et al. 2011; $\mathrm{Ju}$ et al. 2014). In parallel, organisms may upregulate heat shock proteins (HSP), which act as molecular chaperones that help organisms to cope with a wide range of stressors (Sørensen et al. 2003). Such defence mechanisms are expected to be costly and may compromise other fitness components such as reproduction (Alonso-Alvarez et al. 2004; Beaulieu et al. 2015). Mechanisms against heat exposure likely vary across the distribution range of widespread species because of local adaptation, which may disadvantage some populations relative to others in the face of climate warming.

We here investigate variation in body size, fecundity, and physiological defence mechanisms in relation to short-term thermal stress along a latitudinal gradient in the green-veined white butterfly Pieris napi. This species has a wide distribution range and is known to show local adaptation (Günter et al. 2019, 2020). Specifically, we focus on geographic variation in physiological responses to short-term temperature stress, including a simulated hot summer day which will increase in frequency with climate change. Towards this end, we exposed butterflies from replicated Italian, German, and Swedish populations for $24 \mathrm{~h}$ to cold, control, or hot conditions. Physiological responses were scored by measuring MDA and GSH levels as well as gene expression. Because of potential trade-offs between physiological defence mechanisms and other fitness components, we also examined body size and fecundity in parallel to defence mechanisms. Based on a known converse Bergmann cline (Blanckenhorn et al.
2006; Nygren et al. 2008) in body size in P. napi (Petersen 1947; Nylin and Svärd 1991; Günter et al. 2020), we predicted smaller individuals at higher latitude, which may be associated with slower growth and decreased fecundity (Honěk 1993; Blanckenhorn 2000). A reduced fecundity may potentially allow for increased investment into defence mechanisms in individuals from high latitude in response to thermal stress. Accordingly, we predicted an up-regulation of antioxidant defence mechanisms to prevent oxidative damage. Note though that fecundity can be affected by many factors including direct selection, for instance in relation to the time available for egg-laying (Springer and Boggs 1986). This evidently complicates predictions concerning fecundity and associated trade-offs.

\section{Materials and methods}

\section{Study organism and experimental populations}

The green-veined white butterfly Pieris napi L. is a widespread temperate-zone butterfly, occurring throughout Europe and the temperate zone of Asia (Ebert and Rennwald 1993). It is one of the most common butterflies in Europe. Nevertheless, it is predicted to suffer from anthropogenic climate change because of its association with moist habitats (Fox et al. 2015). Larvae feed on a variety of Brassicaceae, with Alliaria petiolata Cavara \& Grande being the most important one. Brassicaceae are also the preferred nectar plants. The species overwinters in the pupal stage (Wiklund et al. 1991) and has typically one to four generations per year (Müller and Kautz 1938; Tolman and Lewington 2008). $P$. napi is polyandrous with males transferring large nuptial gifts to their female partners (Stjernholm and Karlsson 2000; Bergström and Wiklund 2002). Accordingly, males are larger than females (Wiklund and Kaitala 1995).

For this study, we collected freshly enclosed spring generation females along a latitudinal gradient from northern Italy to Sweden. We sampled three replicate populations each in northern Italy (I: Torino $45.11^{\circ} \mathrm{N} / 7.48^{\circ} \mathrm{E}$, Pavia $45.21^{\circ} \mathrm{N} / 9.27^{\circ} \mathrm{E}$, Mantova $45.21^{\circ} \mathrm{N} / 10.75^{\circ} \mathrm{E}$ ), northern Germany (G: Wahrenholz $52.64^{\circ} \mathrm{N} / 10.61^{\circ} \mathrm{E}$, Rathenow $52.65^{\circ} \mathrm{N} / 12.44^{\circ} \mathrm{E}$, Strausberg $52.60^{\circ} \mathrm{N} / 13.86^{\circ} \mathrm{E}$ ), and South Sweden (S: Örebro $59.29^{\circ} \mathrm{N} / 15.01^{\circ} \mathrm{E}$, Eskilstuna $59.36^{\circ} \mathrm{N} / 16.54^{\circ}$ E, Stockholm $58.95^{\circ} \mathrm{N} / 17.58^{\circ}$ E; Fig. 1). Mean annual temperatures follow a latitudinal gradient (Italy: $13{ }^{\circ} \mathrm{C}$, Germany, $9{ }^{\circ} \mathrm{C}$, Sweden: $6{ }^{\circ} \mathrm{C}$ ), while mean annual precipitation is higher in Italy $(865 \mathrm{~mm})$ than in Germany $(570 \mathrm{~mm}$ ) and Sweden (578 mm; Günter et al. 2019). Likewise, the mean temperature during the flight period (May-September; Italy: $20.6{ }^{\circ} \mathrm{C}$, Germany: $15.8^{\circ} \mathrm{C}$, Sweden: $14.2^{\circ} \mathrm{C}$ ) as well as the mean maximum temperature (Italy: $25.9^{\circ} \mathrm{C}$, Germany: $23.4{ }^{\circ} \mathrm{C}$, Sweden: $18.8^{\circ} \mathrm{C}$ ) follow 


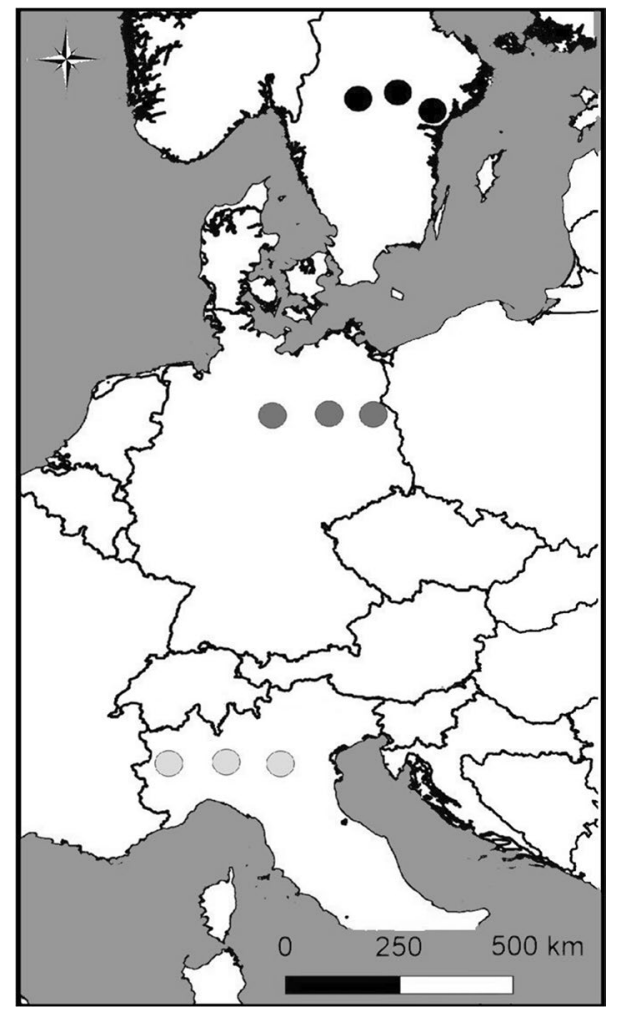

Fig. 1 Sampling locations of Pieris napi individuals used in the present study. Populations were collected in Italy (light grey circles), Germany (dark grey circles), and Sweden (black circles); modified after (Günter et al. 2019)

a latitudinal gradient. Special Report on Extreme Events (IPCC 2012) concludes that there have been major increases in the frequency of warm temperature extremes in Europe, with high confidence for the Mediterranean region. Over North and Central Europe, there is medium confidence in an increase in heat-wave intensity and frequency.

The minimal straight distance between two populations was $73 \mathrm{~km}$, the total latitudinal gradient spanned ca. $1660 \mathrm{~km}$. We collected a total of 74 females from Italy, 94 from Germany, and 76 from Sweden between 19 April and 14 June 2016. All females were subsequently transferred to the University of Greifswald for egg-laying.

We have used this latitudinal gradient and the according populations before to investigate (1) phenotypic variation in field-collected males (Günter et al. 2019) and (2) genetic variation and developmental plasticity (Günter et al. 2020). We found decreased body size, increased wing melanisation, and reduced yellow reflectance with increasing latitude (and altitude in additional populations) in field-collected males (Günter et al. 2019). Using a common garden design, we found that individuals from cooler environments were less heat-tolerant, had a longer development time but were, nevertheless, smaller, and had more strongly melanised wings (Günter et al. 2020). In addition, we showed that a higher developmental temperature speeded up development, reduced body size, potential metabolic activity, and wing melanisation but increased heat tolerance.

\section{Experimental design}

Field-caught females were kept individually in translucent 1-1 plastic pots covered with gauze, which were placed into a climate chamber set at a photoperiod of L18:D6, a constant temperature of $25{ }^{\circ} \mathrm{C}$, and $65 \%$ relative humidity. Females were fed ad libitum with water, a $10 \%$ sugar solution, and additionally flowers (e.g. Sambucus nigra, Taraxacum spec., Senecio spec.). For oviposition, they were provided daily with a fresh cutting of $A$. petiolata. The resulting eggs were collected daily and transferred, separated by females, to elongated, sleeve-like gauze cages. Resulting larvae were fed with fresh cuttings of $A$. petiolata and young rape plants (Brassica napus). All plants were replaced as necessary and the density per cage was limited to a maximum of 40 larvae. Rearing took place in climate chambers under the same conditions as for egg-laying. One day after pupation, resulting pupae were transferred to $500 \mathrm{ml}$ plastic boxes containing moist tissue. On the day of adult eclosion, butterflies were mated within populations, though not allowing siblings to mate. After mating, females were transferred to translucent 1-L plastic pots covered with gauze and containing nectar plants, a leaf of A. petiolata for egg-laying, $10 \%$ sugar solution, and water ad libitum. They were maintained under such conditions for 3 days to lay eggs. Eggs were collected and counted daily. We scored early fecundity as a proxy for reproductive investment to avoid mortality before allocation to treatments (note that animals need to be frozen alive for scoring physiological traits). Butterflies typically lay the majority of eggs early within the oviposition period, and early fecundity correlates strongly with lifetime fecundity (Brakefield et al. 2001; Fischer and Fiedler 2001; Kehl et al. 2015). Furthermore, for scoring trade-offs with short-time physiological responses, current reproductive investment seems more relevant than lifetime investment.

Afterwards, females were evenly divided among three thermal treatments characterized by cold, control, and hot conditions (Fig. 2). The daily temperature cycles used were meant to reflect a cool, average, or hot summer day. All treatments started at $25^{\circ} \mathrm{C}$, with a progressive reduction to $15^{\circ} \mathrm{C}$ to simulate evening/night conditions. Thereafter, temperatures progressively increased to $21^{\circ} \mathrm{C}$ (cold), $27^{\circ} \mathrm{C}$ (average) or $33{ }^{\circ} \mathrm{C}$ (hot). We used short-time exposure to different thermal regimes as according physiological responses can assumed to be very fast. For example, heat shock proteins were found to be up-regulated within hours after 1-h exposure only (Karl et al. 2012). Per treatment, a single climate cabinet was used with identical settings except for thermal profiles (Sanyo MIR-553; Bad Nenndorf, Germany). Males, 


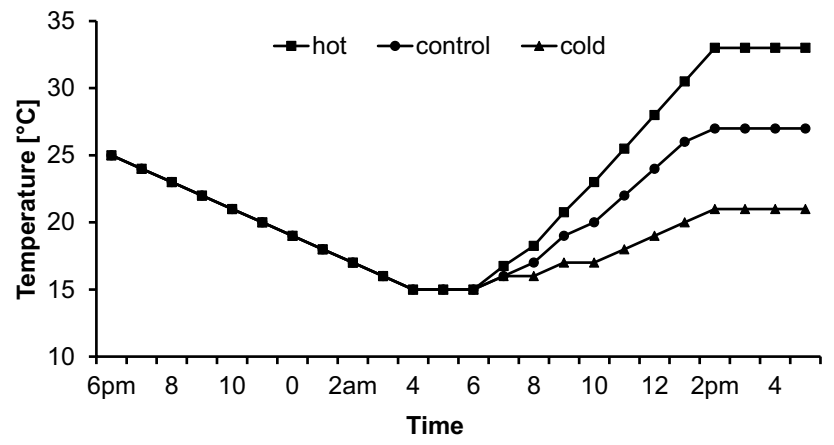

Fig. 2 Temperature profiles of the 3-day cycle treatments. Butterflies were allocated to treatments at 6 p.m. and frozen $24 \mathrm{~h}$ later

in contrast, were allocated to treatments immediately after mating. Butterflies were kept for $24 \mathrm{~h}$ at the respective thermal treatment. Afterwards, they were frozen at $-80{ }^{\circ} \mathrm{C}$ for later analyses. Offspring sample sizes were 0,47 , and 13 for Swedish, 60, 77, and 57 for German, and 59, 41, and 39 for Italian populations.

The head, wings, and legs were removed from frozen butterflies, and the thorax and abdomen were separated before being weighed (KERN ABJ-120-4M). For each individual (except those used for transcriptome analyses, see below), we measured thorax mass, abdomen mass, and two physiological parameters related to oxidative stress: a marker of antioxidant defence, glutathione (GSH, a non-enzymatic antioxidant), and a marker of oxidative damage, malondialdehyde (MDA, a marker of lipid peroxidation). Glutathione is a central endogenous antioxidant protecting cells against the action of ROS by scavenging them directly or through enzymatic reactions (Aquilano et al. 2014), while MDA is a marker of oxidative damage on lipids, the class of biomolecules most affected by the action of ROS (Del Rio et al. 2005). For measuring GSH and MDA, we used the methods detailed in Günter et al. (2020). In short, we homogenized thoraces and abdomen with a TissueLyser (QIAGEN, The Netherlands) through $1 \mathrm{~min}$ and then cooled down for 1 min on dry ice. This procedure was repeated three times. The resulting homogenates were centrifuged at $16,249 \mathrm{~g}$ for $30 \mathrm{~min}$ at $4{ }^{\circ} \mathrm{C}$. Then, the supernatants were transferred to new tubes and centrifuged once again for $15 \mathrm{~min}$. The resulting supernatants were used to analyse total protein concentration, MDA, and GSH. Total protein concentration was determined at $595 \mathrm{~nm}$ using a microplate reader (Epoch 2, BIO-TEK Instruments) according to the Bradford method.

GSH levels were assessed with a spectrophotometric method that involves oxidation of GSH by 2-nitrobenzoic acid to the yellow derivative 5'-thio-2-nitrobenzoic acid (TNB). A GSH stock solution was prepared from $100 \mathrm{mM}$ GSH and diluted to a standard series. Per $1 \mathrm{mg}$ protein sample, sulfosalicylic acid (end concentration $4 \%$ ) was added in
$150 \mu \mathrm{l}$ volume and incubated overnight at $4{ }^{\circ} \mathrm{C}$. Afterwards, samples were centrifuged at $16,249 \mathrm{~g}$ for $30 \mathrm{~min}$ at $4{ }^{\circ} \mathrm{C}$, and neutralized using $1 \mathrm{M} \mathrm{NaOH}$ until reaching $\mathrm{pH} 7$. Each probe was diluted using a factor of 1:2 and 1:4. Standards, samples, and dilutions were transferred to a microplate. Then, $40 \mu 11.5 \mathrm{mM}$ 2-nitrobenzoic acid was added to each well to start the assay. Absorbance was measured at $412 \mathrm{~nm}$ with 30 kinetic cycles. MDA concentrations were measured with a commercially available Microplate Assay Kit (CAK1011, Cohesion Bioscience) by reading the maximum absorbance at $532 \mathrm{~nm}$ and $37{ }^{\circ} \mathrm{C}$ (Meng et al. 2009). GSH and MDA values were corrected by protein content.

\section{Transcriptome analyses}

We used transcriptome analyses to prove that the treatments used actually imposed thermal stress and to investigate which physiological pathways are activated by butterflies exposed to hot conditions. For logistic reasons, analyses were restricted to German individuals previously exposed to control or hot conditions. We randomly selected two pairs of full-sib sisters per population ( $n=12$ individuals), with one sibling being exposed to control and the other to hot conditions. Whole thoraces and abdomens were used for RNA extraction. RNA isolation was carried out using TRIZOL (Invitrogen) according to the manufacturer's instructions, using $1 \mathrm{~mL}$ of TRIZOL per individual. Animal tissue was disrupted using a tissue lyser (Qiagen 20.747.0001; bead beating with $5 \mathrm{~mm}$ steel beads) for $1 \mathrm{~min}$ at $30 \mathrm{~Hz}$. For RNA purification, the RNeasy Mini kit (Qiagen 74106) was used. Construction of the RNA library and transcriptomic sequencing were performed by LGC Genomics $\mathrm{GmbH}$ (Berlin, Germany). For details, see Supplementary Material S1. Changes in the level of gene expression are presented as $\log 2$-fold change $(\log 2 \mathrm{FC})$ values. They show whether genes are up- or down-regulated and how strongly so. A value $<1$ reflects a down-regulation, while a value $>1$ reflects an up-regulation.

\section{Statistical analyses}

Data on egg number, morphology, and physiology were analysed using general linear mixed models (GLMMs) with country (Italy, Germany, Sweden), sex, treatment (cool, benign, hot), and all resulting interactions as fixed factors, and replicate population as random effect nested within country. Egg numbers were analysed only for females irrespective of thermal treatment (as eggs were collected before allocation to treatments). MDA, GSH, and egg number were square root-transformed prior to analyses to meet GLMM requirements. Models were constructed by stepwise backward removal of non-significant interactions. For egg number, we additionally performed covariance analyses 
by adding thorax and abdomen mass or MDA and GSH as covariates. Throughout the text, means are given \pm 1 SE. All statistical tests were performed with Statistica 12.0 (Tulsa, StatSoft, OK).

\section{Results}

\section{Egg number, morphology, and physiology}

The number of eggs collected over a 3-day period following mating was significantly higher in Italian $(57.1 \pm 5.3$ eggs) than Swedish females $(15.8 \pm 5.2)$, with German ones showing intermediate values $(43.7 \pm 3.8$; Tukey HSD after GLMM: I $\geq \mathrm{G} \geq \mathrm{S} ; F_{2,9}=4.9, P=0.037$; population $\left.F_{5,151}=0.9, P=0.458\right)$. Thorax mass, abdomen mass, MDA, or GSH were not related to egg number significantly when added as covariates (all $P$ values $>0.10$ ). Origin significantly affected thorax mass, abdomen mass, MDA, and GSH, while significant population differences were found for abdomen mass and GSH only (Table 1). Thorax and abdomen mass as well as MDA decreased from South (Italy) to North (Sweden), while the opposite pattern was observed for GSH (Fig. 3). For abdomen mass, the latitudinal gradient was restricted to females (significant country-by-sex interaction; Fig. 3b). Thermal treatment had a significant effect on GSH only, with values being higher under control than cold or hot conditions (control: $0.667 \pm 0.052 \mu \mathrm{M} / \mathrm{mg}$ protein $>$ cold: $0.542 \pm 0.025=$ hot: $0.564 \pm 0.027$; Tukey HSD after GLMM). This pattern was, however, only significant in German butterflies, although there was a similar trend in Swedish butterflies (significant country by treatment interaction; Fig. 3c).
Table 1 Results of general linear mixed models testing for the effects of country (fixed factor), population (random, nested within country), sex and temperature treatment (both fixed) on thorax mass, abdomen mass, glutathione (GSH), and malondialdehyde (MDA) in Pieris napi from a latitudinal gradient

\begin{tabular}{|c|c|c|c|c|}
\hline Thorax mass & MS & $\mathrm{DF}$ & $F$ & $P$ \\
\hline Country & $5.8 \times 10^{-04}$ & 2,15 & 21.1 & $<0.0001$ \\
\hline Population [country] & $2.0 \times 10^{-05}$ & 5,381 & 0.3 & 0.8907 \\
\hline Sex & $1.9 \times 10^{-04}$ & 1,381 & 3.3 & 0.0706 \\
\hline Treatment & $2.1 \times 10^{-06}$ & 2,381 & 0.0 & 0.9651 \\
\hline Error & $5.9 \times 10^{-05}$ & 381 & & \\
\hline Abdomen mass & MS & DF & $F$ & $P$ \\
\hline Country & $1.0 \times 10^{-03}$ & 2,6 & 5.5 & 0.0417 \\
\hline Population [country] & $1.7 \times 10^{-04}$ & 5,341 & 2.4 & 0.0376 \\
\hline Sex & $9.7 \times 10^{-03}$ & 1,341 & 112.0 & $<0.0001$ \\
\hline Treatment & $1.3 \times 10^{-04}$ & 2,341 & 1.7 & 0.1817 \\
\hline Country $\times$ sex & $7.8 \times 10^{-04}$ & 2,341 & 7.0 & 0.0011 \\
\hline Error & $7.1 \times 10^{-05}$ & 341 & & \\
\hline GSH & MS & DF & $F$ & $P$ \\
\hline Country & 3.316 & 2,6 & 46.0 & 0.0002 \\
\hline Population [country] & 0.082 & 5,343 & 2.3 & 0.0441 \\
\hline Sex & 0.039 & 1,343 & 1.1 & 0.2941 \\
\hline Treatment & 0.172 & 2,343 & 4.8 & 0.0084 \\
\hline Country $\times$ treatment & 0.103 & 4,343 & 2.9 & 0.0219 \\
\hline Error & 0.036 & 343 & & \\
\hline MDA & MS & DF & $F$ & $P$ \\
\hline Country & 0.022 & 2,11 & 5.9 & 0.0179 \\
\hline Population [country] & 0.003 & 5,377 & 0.5 & 0.7639 \\
\hline Sex & 0.003 & 1,377 & 0.5 & 0.4750 \\
\hline Treatment & 0.005 & 2,377 & 0.7 & 0.4791 \\
\hline Error & 0.006 & 377 & & \\
\hline
\end{tabular}

Models were constructed by stepwise backwards elimination of non-significant interactions. Significant $P$ values are given in bold 

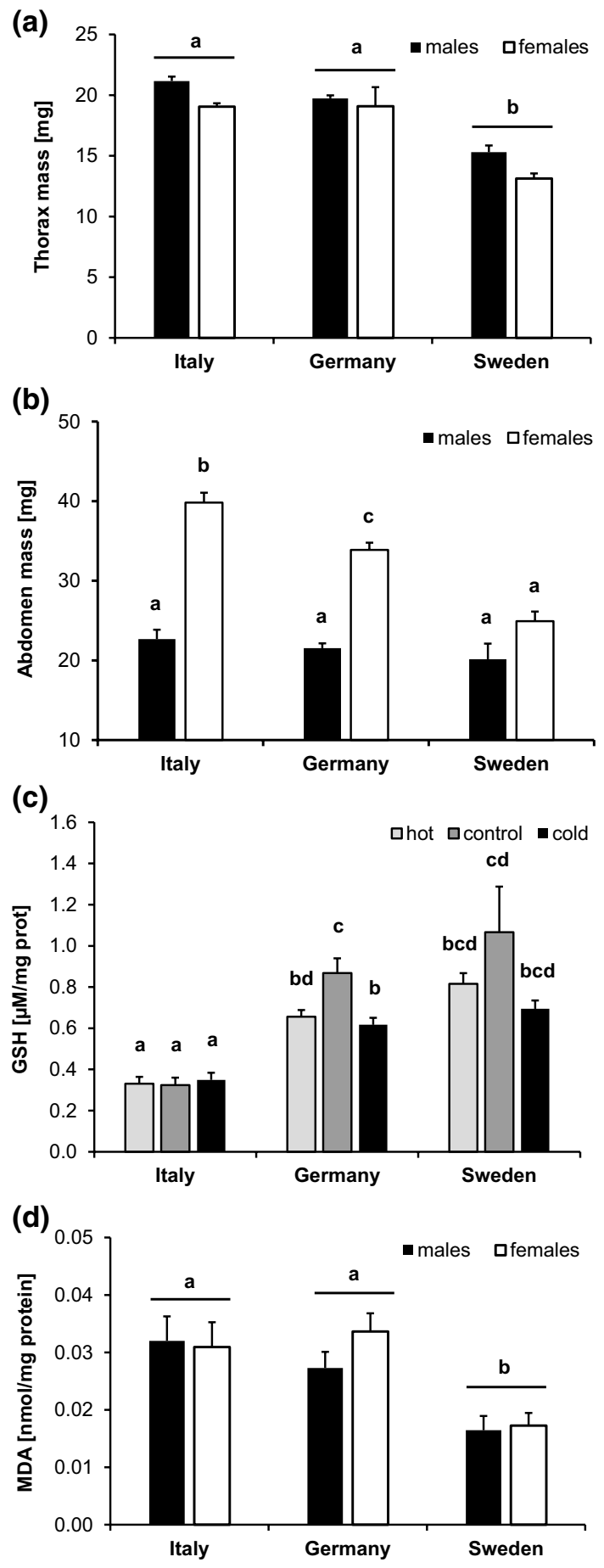

Fig. 3 Means \pm SE for thorax mass (a), abdomen mass (b), GSH (c), and MDA (d) for Pieris napi in relation to country of origin and sex $(\mathbf{a}, \mathbf{b}, \mathbf{d})$ or treatment $(\mathbf{c})$. Different letters above bars show significant differences among groups (Tukey HSD after GLMM)

\section{Gene expression}

In German female butterflies, we found 25 annotated transcripts that were significantly up-regulated under hot compared with control temperatures (Supplementary Material S2). $\log 2 \mathrm{FC}$ values for these transcripts ranged between 3.1 and 8.2. As several transcripts belonged to the same gene, we identified only 15 according genes (Table 2 ). These genes were mainly associated with cellular processes and signalling (11). Two genes were related to information storage and processing, while the function of the two remaining genes was unknown. Nine out of the fifteen genes were molecular chaperones, two were involved in 'translation, ribosomal structure and biogenesis', and two in 'signal transduction mechanisms' (two had unknown functions). The genes most strongly up-regulated were heat shock protein 68, lethal (2) essential for life, and Valyl-tRNA synthetase (Fig. 4).

\section{Discussion}

We found clinal variation in body mass, which decreased with increasing latitude. Thus, individuals from warmer (Italy) rather than cooler regions (Sweden) were larger, confirming the known converse Bergmann's rule in P. napi (Petersen 1947; Nylin and Svärd 1991). We thus assume that warmer conditions are more beneficial for the development of $P$. napi allowing for larger body size (David and Gardiner 1962; Angilletta and Dunham 2003), causing this genetically based cline. Several examples for converse Bergmann size clines have already been reported (Blanckenhorn and Demont 2004; Blanckenhorn et al. 2006), for instance based on short season length and low ambient temperatures at higher latitudes constraining growth opportunities (Van Doorslaer and Stoks 2005).

Females had much heavier abdomen than males, which is likely related to egg production. As the males and females used here were mated, the sexual difference in abdomen mass may also arise from the large spermatophores that males transfer to females in P. napi (up to 15\% of the males' initial body mass; Svärd and Wiklund 1989; Wiklund and Kaitala 1995). In general, high abdomen mass in female insects is related to reproductive investment and hence high fecundity (Tammaru et al. 1996; Berwaerts et al. 2002). Accordingly, we found that early fecundity showed the same pattern than abdomen mass, with more eggs being laid by heavier Italian than by lighter Swedish females. This suggests that higher female abdomen mass enables high early fecundity in southern populations. Perhaps, fast reproduction is advantageous in warmer climates, as large egg numbers can be laid during a single warm day allowing for long activity.

Interestingly, MDA, which is a degradation product of polyunsaturated fatty acids and thus a marker for lipid peroxidation through ROS (Liu et al. 1997; Janssens et al. 2017), was lower in Swedish than in Italian or German individuals. 
Table 2 Functional annotation of transcripts up-regulated in Pieris napi from Germany at the higher temperature, including protein and gene name, description, molecular main, and subrole

\begin{tabular}{|c|c|c|c|c|c|}
\hline gi No. & Protein name & Gene & Description & Main role & Subrole \\
\hline 17738165 & Heat shock protein 68 & Hsp68 & $\begin{array}{l}\text { Molecular chaperones HSP70/HSC70, HSP70 } \\
\text { superfamily }\end{array}$ & Cellular & Chaperones \\
\hline 1170372 & Heat shock protein $70 \mathrm{~A} 1$ & Hsp70A1 & $\begin{array}{l}\text { Molecular chaperones HSP70/HSC70, HSP70 } \\
\text { superfamily }\end{array}$ & Cellular & Chaperones \\
\hline 665390828 & Heat shock $70 \mathrm{kDa}$ protein cognate 3 & Hsc70-3 & $\begin{array}{l}\text { Molecular chaperones GRP78/BiP/KAR2, HSP70 } \\
\text { superfamily }\end{array}$ & Cellular & rones \\
\hline 3096951 & Heat shock protein 90 & Hsp90 & Molecular chaperone, HSP90 family & Cellular & ones \\
\hline 54642233 & Heat shock protein 83 & Hsp83 & Molecular chaperone, HSP90 family & Cellular & Chaperones \\
\hline 442624575 & Protein lethal (2) essential for life & 1(2)efl & Alpha crystallins & Cellular & Chaperones \\
\hline 17562026 & Heat shock protein $16.1 / 16.11$ & Hsp-16.1 & Alpha crystallins & Cellular & Chaperones \\
\hline 81909571 & Heat shock protein beta- 6 & Hspb6 & Alpha crystallins & Cellular & Chaperones \\
\hline 197102236 & DnaJ homolog sub-family A member 1 & DNAJA1 & Molecular chaperone, DnaJ superfamily & Cellular & Chaperones \\
\hline 21542452 & Valine-tRNA ligase, mitochondrial 1 & TWN2 & Valyl-tRNA synthetase & Information & Translation \\
\hline 74870264 & Putative tRNA pseudo-uridine synthase & Pus10 & Predicted pseudouridylate synthase & Information & Translation \\
\hline 21706506 & Leucine-rich repeat neuronal protein 2 & LRRN2 & Membrane glycol-protein LIG-1 & Cellular & Transduction \\
\hline 75273276 & Probable protein phosphatase $2 \mathrm{C} 38$ & $\mathrm{PP} 2 \mathrm{C} 38$ & $\begin{array}{l}\text { Protein phosphatase } 2 \mathrm{C} / \text { pyruvate dehydrogenase } \\
\text { phosphatase }\end{array}$ & Cellular & Transduction \\
\hline 130398 & Retrovirus-related Pol polyprotein & Pol & Unknown & - & - \\
\hline 1326016 & Transposon Ty3-I Gag-Pol polyprotein & TY3B-I & Unknown & - & - \\
\hline
\end{tabular}

Main roles: cellular — cellular processes and signalling; information-information storage and processing. Subroles: chaperones-posttranslational modification, protein turnover, chaperones; translation - translation, ribosomal structure and biogenesis; transduction—signal transduction mechanisms

Fig. 4 Overview of the genes being most strongly up-regulated under hot compared to control temperatures in Pieris napi from Germany. Only genes with $\log 2 \mathrm{FC}$ values $>6$ are shown

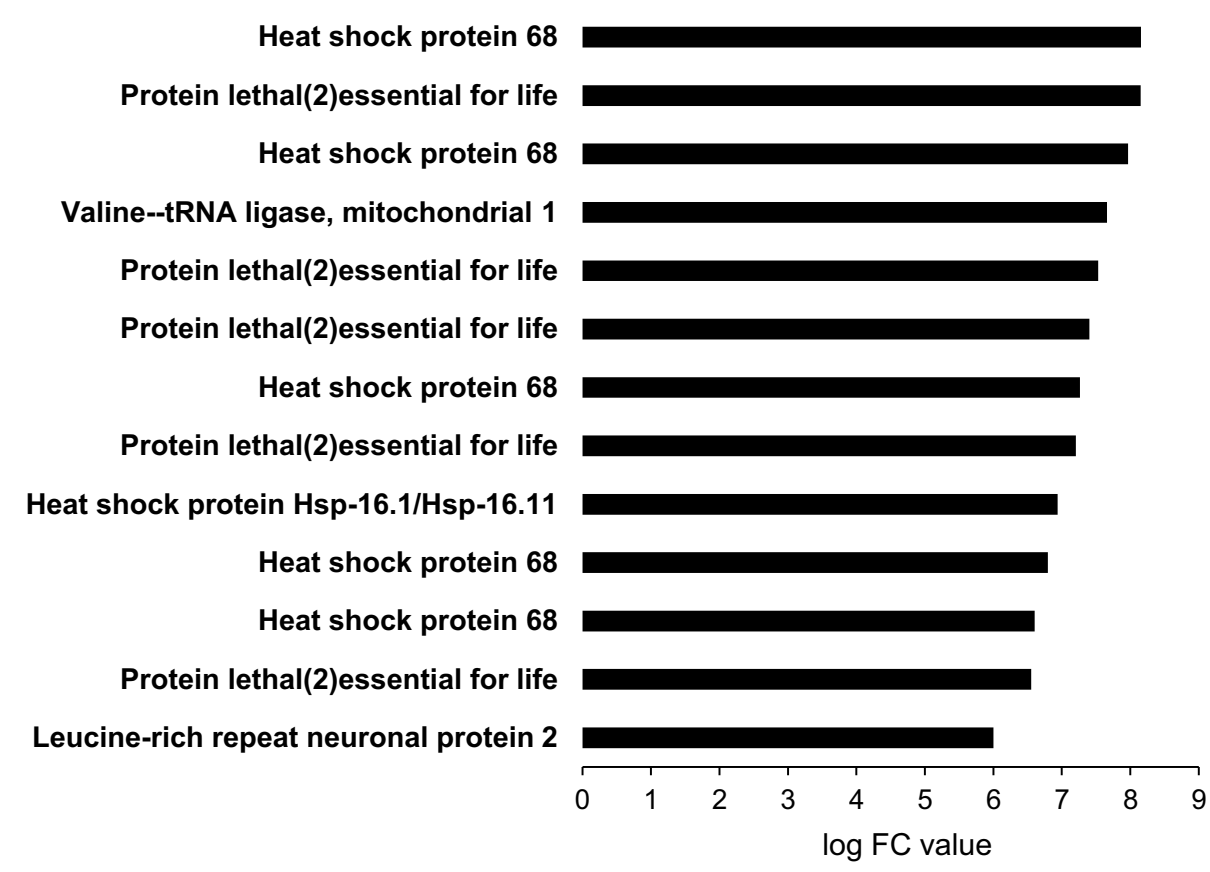

The reduced oxidative damage may be related to relatively high levels of antioxidants (here: GSH) in Swedish individuals. The antioxidant GSH is known to efficiently remove ROS (Hayes and McLellan 1999; Kregel and Zhang 2007).
This suggests that butterflies from higher latitudes invest more strongly into self-maintenance mechanisms than butterflies from lower latitudes. This higher investment may in turn be, at least partly, enabled by the lower reproductive 
investment and the overall slower lifestyle (Günter et al. 2020) of Swedish animals. Indeed, variation in antioxidative defences has been found in relation to reproduction, larval developmental time, growth rate, wing melanisation rate, and heat resistance (Günter et al. 2019, 2020). However, we did not find a direct link between fecundity and oxidative markers. Thus, despite indications for a micro-evolutionary trade-off, a similar physiological trade-off could not be confirmed. We, therefore, have to reject our hypothesis that females showing a high reproductive investment inevitably suffer more from oxidative stress. This negative finding may result from (1) measuring only two markers related to oxidative stress, (2) too short exposure to different temperature profiles, (3) using temperatures that were not extreme enough (despite a strong up-regulation of molecular chaperones, see below), or (4) not enough time for physiological responses to occur. Regarding the latter, very little is known on the temporal dynamics of the up-regulation of antioxidant defences and the occurrence of oxidative damage (Schlorff et al. 1999). Anyway, short-time exposure to mildly stressful conditions does not seem to necessarily result in a tradeoff between maintenance and reproduction. In line with this conclusion, temperature treatment did not affect MDA. GSH, in contrast, was significantly affected by temperature. Interestingly, highest levels were found under control conditions, which may indicate that hot as well as cold conditions may interfere with GSH. The decrease in GSH under hot conditions is likely due to a higher production of ROS under such conditions and by the resulting higher oxidation of GSH into GSSG (Hayes and McLellan 1999; Kregel and Zhang 2007).

The transcriptome analyses also showed no pronounced variation among temperature treatments in markers related to oxidative stress. However, several molecular chaperones, including heat shock proteins and alpha crystallins, were up-regulated under hot conditions, which is a well-known response to heat stress across various taxa (Sørensen et al. 2001; Karl et al. 2009). These proteins participate in folding and unfolding of proteins and help maintaining their secondary structure under extreme environmental conditions (Parsell and Lindquist 1993). Our results on gene expression confirm that the treatments used were appropriate for elucidating short-term physiological responses, at least with regard to the heat shock response in German females.

\section{Conclusions}

Our study revealed clinal variation in body mass and fecundity (both being higher in warmer regions), and oxidative defence mechanisms. Regarding the latter, oxidative damage was lowest in Swedish animals, having at the same time the highest levels of the antioxidant GSH. This may reflect geographical variation in life styles and accordingly antioxidant defence mechanisms. Swedish individuals showed the lowest early fecundity in the current study, and are also known to have the lowest growth rates (Günter et al. 2020). Thus, Swedish individuals seem to have a slower life style and to invest more strongly into maintenance, while Italian individuals show the opposite pattern, which may reflect a 'pace-of-life' syndrome (Montiglio et al. 2018). Note though that we could not show a direct link between fecundity and physiological parameters. Exposing individuals for $24 \mathrm{~h}$ to different temperature treatments caused an increased expression of molecular chaperones, but did not affect oxidative damage, while levels of the antioxidant GSH were reduced under cold and hot conditions. We conclude that short-term exposure to heat stress does not substantially affect oxidative balance. The effects which longer exposure times though may have on oxidative stress and its relations to reproduction and maintenance deserves further attention.

Acknowledgements Open Access funding provided by Projekt DEAL. We would like to thank Ines Welzel and Kasimir Freiberg for help with processing butterflies, and Jan-Peter Hildebrandt for fruitful discussions. This research was funded by the DFG research training group response (DFG GRK 2010).

Author contribution statement $\mathrm{FG}, \mathrm{KFi}$, and $\mathrm{MB}$ conceived and designed the experiments. FG performed the experiments. NT analysed oxidative markers and $\mathrm{KFr}$ transcriptome data. FG and KFi analysed the data. FG, $\mathrm{KFi}$, and MB wrote the manuscript.

Open Access This article is licensed under a Creative Commons Attribution 4.0 International License, which permits use, sharing, adaptation, distribution and reproduction in any medium or format, as long as you give appropriate credit to the original author(s) and the source, provide a link to the Creative Commons licence, and indicate if changes were made. The images or other third party material in this article are included in the article's Creative Commons licence, unless indicated otherwise in a credit line to the material. If material is not included in the article's Creative Commons licence and your intended use is not permitted by statutory regulation or exceeds the permitted use, you will need to obtain permission directly from the copyright holder. To view a copy of this licence, visit http://creativecommons.org/licenses/by/4.0/.

\section{References}

Addo-Bediako A, Chown SL, Gaston KJ (2000) Thermal tolerance, climatic variability and latitude. Proc R Soc B 267:739-745

Alonso-Alvarez C, Bertrand S, Devevey G et al (2004) Increased susceptibility to oxidative stress as a proximate cost of reproduction. Ecol Lett 7:363-368. https://doi.org/10.111 $1 /$ j.1461-0248.2004.00594.x

Angilletta MJJ, Dunham AE (2003) The temperature-size rule in ectotherms: simple evolutionary explanations may not be general. Am Soc Nat 162:332-342. https://doi.org/10.1086/377187

Aquilano K, Baldelli S, Ciriolo MR (2014) Glutathione: new roles in redox signalling for an old antioxidant. Front Pharmacol 5:1-13. https://doi.org/10.3389/fphar.2014.00196

Arnett AE, Gotelli NJ (1999) Bergmann's rule in the ant lion Myrmeleon immaculatus DeGeer (Neuroptera: Myrmeleontidae): 
geographic variation in body size and heterozygosity. J Biogeogr 26:275-283. https://doi.org/10.1046/j.1365-2699.1999.00271.x

Beaulieu M, Geiger RE, Reim E et al (2015) Reproduction alters oxidative status when it is traded-off against longevity. Evolution (NY) 69:1786-1796. https://doi.org/10.1111/evo.12697

Bergström J, Wiklund C (2002) Effects of size and nuptial gifts on butterfly reproduction: can females compensate for a smaller size through male-derived nutrients? Behav Ecol Sociobiol 52:296302. https://doi.org/10.1007/s00265-002-0512-0

Berwaerts K, Van Dyck H, Aerts P (2002) Does flight morphology relate to flight performance? An experimental test with the butterfly Pararge aegeria. Funct Ecol 16:484-491. https://doi.org/1 0.1046/j.1365-2435.2002.00650.x

Blanckenhorn WU (2000) The evolution of body size: what keeps organisms small? Q Rev Biol 75:385-407

Blanckenhorn WU, Demont M (2004) Bergmann and converse Bergmann latitudinal clines in arthropods: two ends of a continuum? Integr Comp Biol 44:413-424. https://doi.org/10.1093/ $\mathrm{icb} / 44.6 .413$

Blanckenhorn WU, Stillwell RC, Young KA et al (2006) When Rensch meets Bergmann: does sexual size dimorphism change systematically with latitude? Evolution (NY) 60:2004-2011. https://doi. org/10.1554/06-110.1

Brakefield PM, El Filali E, Van der Laan R et al (2001) Effective population size, reproductive success and sperm precedence in the butterfly, Bicyclus anynana, in captivity. J Evol Biol 14:148-156. https://doi.org/10.1046/j.1420-9101.2001.00248.x

Chown SL, Klok JC (2003) Altitudinal body size clines: latitudinal effects associated with changing seasonality. Ecography (Cop) 26:445-455. https://doi.org/10.1034/j.1600-0587.2003.03479.x

David WAL, Gardiner BOC (1962) Oviposition and the larvae and pupae of Pieris brassicae (L.) in a laboratory culture. Bull Entomol Res 53:417-436. https://doi.org/10.1017/S00074853000479 82

Del Rio D, Stewart AJ, Pellegrini N (2005) A review of recent studies on malondialdehyde as toxic molecule and biological marker of oxidative stress. Nutr Metab Cardiovasc Dis 15:316-328. https:// doi.org/10.1016/j.numecd.2005.05.003

Deutsch CA, Tewksbury JJ, Huey RB et al (2008) Impacts of climate warming on terrestrial ectotherms across latitude. Proc Natl Acad Sci USA 105:6668-6672

Diffenbaugh NS, Pal JS, Trapp RJ, Giorgi F (2005) Fine-scale processes regulate the response of extreme events to global climate change. Proc Natl Acad Sci U S A 102:15774-15778

Easterling DR, Meehl GA, Parmesan C et al (2000) Climate extremes: observations, modeling, and impacts. Science 289:2068-2074. https://doi.org/10.1126/science.289.5487.2068

Ebert G, Rennwald E (1993) Die Schmetterlinge Baden- Württembergs vol 1: Tagfalter 1, 1st edn. Ulmer, Stuttgart

Ellers J, Boggs CL (2002) The evolution of wing color in Colias butterflies: heritability, sex linkage, and population divergence. Evolution (NY) 56:836-840. https://doi.org/10.1554/00143820(2002)056[0836:TEOWCI]2.0.CO;2

Fischer K, Fiedler K (2001) Effects of adult feeding and temperature regime on fecundity and longevity in the butterfly Lycaena hippothoe. J Lepid Soc 54:91-96

Fox R, Brereton T, Asher J et al (2015) The state of the UK's butterflies 2015. Wareham, Dorset

Franke K, Karl I, Centeno TP et al (2019) Effects of adult temperature on gene expression in a butterfly: identifying pathways associated with thermal acclimation. BMC Evol Biol 19:1-16. https://doi. org/10.1186/s12862-019-1362-y

Günter F, Beaulieu M, Brunetti M et al (2019) Latitudinal and altitudinal variation in ecologically important traits in a widespread butterfly. Biol J Linn Soc 20:1-14. https://doi.org/10.1093/bioli nnean/blz133
Günter F, Beaulieu M, Freiberg KF et al (2020) Genotype-environment interactions rule the response of a widespread butterfly to temperature variation. J Evol Biol 00:1-10. https://doi.org/10.1111/ jeb. 13623

Hansen J, Sato M, Ruedy R (2012) Perception of climate change. Proc Natl Acad Sci USA 109:E2415-E2423. https://doi.org/10.1073/ pnas.1205276109

Hayes JD, McLellan LI (1999) Glutathione and Glutathione-dependent enzymes represent a co-ordinately regulated defence against oxidative stress. Free Radic Res 31:273-300

Hoffmann AA, Rieseberg LH (2008) Revisiting the impact of inversions in evolution: from population genetic markers to drivers of adaptive shifts and speciation? Annu Rev Ecol Evol Syst 39:2142. https://doi.org/10.1146/annurev.ecolsys.39.110707.173532

Honěk A (1993) Intraspecific variation in body size and fecundity in insects: A general relationship. Oikos 66:483-492. https://doi. org/10.2307/3544943

IPCC (2012) IPCC Report. Managing the risks of extreme events and disasters to advance climate change adaptation. Cambridge University Press, Cambridge, New York, p 582

Janssens L, Tüzün N, Stoks R (2017) Testing the time-scale dependence of delayed interactions: a heat wave during the egg stage shapes how a pesticide interacts with a successive heat wave in the larval stage. Environ Pollut 230:351-359. https://doi. org/10.1016/j.envpol.2017.06.082

Ju R-T, Gao L, Zhou X-H, Li B (2014) Physiological responses of Corythucha ciliata adults to high temperatures under laboratory and field conditions. J Therm Biol 45:15-21

Kapun M, Fabian DK, Goudet J, Flatt T (2016) Genomic evidence for adaptive inversion clines in Drosophila melanogaster. Mol Biol Evol 33:1317-1336. https://doi.org/10.1093/molbev/msw016

Karl I, Sørensen JG, Loeschcke V, Fischer K (2009) HSP70 expression in the Copper butterfly Lycaena tityrus across altitudes and temperatures. J Evol Biol 22:172-178. https://doi.org/10.111 1/j.1420-9101.2008.01630.x

Karl I, Michalowsky C, Sørensen JG et al (2012) Effects of rearing and induction temperature on the temporal dynamics of heat shock protein 70 expression in a butterfly. Physiol Entomol 37:103-108. https://doi.org/10.1111/j.1365-3032.2011.00814.x

Kawecki TJ, Ebert D (2004) Conceptual issues in local adaptation. Ecol Lett 7:1225-1241. https://doi.org/10.111 1/j.1461-0248.2004.00684.x

Kehl T, Dublon IAN, Fischer K (2015) Young male mating success is associated with sperm number but not with male sex pheromone titres. Front Zool 12:1-11. https://doi.org/10.1186/s1298 3-015-0124-y

Kregel KC, Zhang HJ (2007) An integrated view of oxidative stress in aging: basic mechanisms, functional effects, and pathological considerations. Am J Physiol Regul Integr Comp Physiol 292:18-36. https://doi.org/10.1152/ajpregu.00327.2006

Lalouette L, Williams CM, Hervant F et al (2011) Metabolic rate and oxidative stress in insects exposed to low temperature thermal fluctuations. Comp Biochem Physiol Part A 158:229-234. https ://doi.org/10.1016/j.cbpa.2010.11.007

Liu J, Yeo HC, Doniger SJ, Ames BN (1997) Assay of aldehydes from lipid peroxidation: gas chromatography-mass spectrometry compared to thiobarbituric acid. Analaytical Biochem 245:161-166

Meehl GA, Tebaldi C (2004) More intense, more frequent, and longer lasting heat waves in the 21st century. Science 305:994-997

Meng J-Y, Zhang C-Y, Zhu F et al (2009) Ultraviolet light-induced oxidative stress: effects on antioxidant response of Helicoverpa armigera adults. J Insect Physiol 55:588-592. https://doi. org/10.1016/j.jinsphys.2009.03.003

Montiglio PO, Dammhahn M, Dubuc Messier G, Réale D (2018) The pace-of-life syndrome revisited: the role of ecological conditions 
and natural history on the slow-fast continuum. Behav Ecol Sociobiol 72:1-9. https://doi.org/10.1007/s00265-018-2526-2

Müller L, Kautz H (1938) Pieris bryoniae O. und Pieris napi L. Österreichischer Entomologen-Verein, Wien

Nygren GH, Bergström A, Nylin S (2008) Latitudinal body size clines in the butterfly Polyommatus icarus are shaped by geneenvironment interactions. J Insect Sci 8:1-13. https://doi. org/10.1673/031.008.4701

Nylin S, Svärd L (1991) Latitudinal patterns in the size of European butterflies. Holarct Ecol 14:192-202

Parmesan C, Yohe G (2003) A globally coherent fingerprint of climate change impacts across natural systems. Nature 421:37-42

Parsell DA, Lindquist S (1993) The function of heat-shock proteins in stress tolerance: degradation and reactivation of damaged proteins. Annu Rev Genet 27:437-496. https://doi.org/10.1146/annur ev.genet.27.1.437

Petersen B (1947) Die geographische Variation einiger Fennoskandischer Lepidopteren. Zool Bidr från Uppsala 26:329-531

Pigliucci M (2001) Phenotypic plasticity: beyond nature and nurture, 1 st edn. John Hopkins University Press, Baltimore

Robinson SJW, Partridge L (2001) Temperature and clinal variation in larval growth efficiency in Drosophila melanogaster. J Evol Biol 14:14-21. https://doi.org/10.1046/j.1420-9101.2001.00259.x

Schlorff EC, Husain K, Somani SM (1999) Dose- and time-dependent effects of Ethanol on plasma antioxidant system in rat. Alcohol 18:203-214. https://doi.org/10.1016/S0741-8329(98)00039-1

Sørensen JG, Dahlgaard J, Loeschcke V (2001) Genetic variation in thermal tolerance among natural populations of Drosophila buzzatii: down regulation of Hsp70 expression and variation in heat stress resistance traits. Funct Ecol 15:289-296. https://doi.org/10 $.1046 / \mathrm{j} .1365-2435.2001 .00525 . x$

Sørensen JG, Kristensen TN, Loeschcke V (2003) The evolutionary and ecological role of heat shock proteins. Ecol Lett 6:1025-1037. https://doi.org/10.1046/j.1461-0248.2003.00528.x

Springer C, Boggs CL (1986) Resource allocation to oocytes: heritable variation with altitude in Colias philodice eriphyle (Lepidoptera). Am Nat 127:252-256. https://doi.org/10.1109/ICALT.2010.162
Stillwell RC, Fox CW (2009) Geographic variation in body size, sexual size dimorphism and fitness components of a seed beetle: local adaptation versus phenotypic plasticity. Oikos 118:703-712. https ://doi.org/10.1111/j.1600-0706.2008.17327.x

Stjernholm F, Karlsson B (2000) Nuptial gifts and the use of body resources for reproduction in the green-veined white butterfly Pieris napi. Proc R Soc B Biol Sci 267:807-811. https://doi. org/10.1098/rspb.2000.1075

Svärd L, Wiklund C (1989) Mass and production rate of ejaculates in relation to monandry / polyandry in butterflies. Behav Ecol Sociobiol 24:395-402

Tammaru T, Kaitaniemi P, Ruohomäki K (1996) Realized fecundity in Epirrita autumnata (Lepidoptera: Geometridae): relation to body size and consequences to population dynamics. Oikos 77:407416. https://doi.org/10.2307/3545931

Tolman T, Lewington R (2008) Collins butterfly guide, 3rd edn. HarperCollins Publishers, London

Van Doorslaer W, Stoks R (2005) Growth rate plasticity to temperature in two damselfly species differing in latitude: contributions of behaviour and physiology. Oikos 111:599-605. https://doi.org/1 0.1111/j.1600-0706.2005.14335.x

Wiklund C, Kaitala A (1995) Sexual selection for large male size in a polyandrous butterfly: the effect of body size on male versus female reproductive success in Pieris napi. Behav Ecol 6:6-13. https://doi.org/10.1093/beheco/6.1.6

Wiklund C, Nylin S, Forsberg J (1991) Sex-related variation in growth rate as a result of selection for large size and protandry in a bivoltine butterfly, Pieris napi. Oikos 60:241-250. https://doi. org/10.2307/3544871

Zhang S, Fu W, Li N et al (2015) Antioxidant responses of Propylaea japonica (Coleoptera: Coccinellidae) exposed to high temperature stress. J Insect Physiol 73:47-52. https://doi.org/10.1016/j.jinsp hys.2015.01.004 